УДК 616.718.4-001.5-089.2-053.2(045)

DOI: http://dx.doi.org/10.15674/0030-59872021210-16

\title{
Остеосинтез у разі переломів шийки та вертлюгової зони стегнової кістки в дітей
}

\author{
О. К. Попсуйшапка ${ }^{1}$, С. Б. Довгань ${ }^{1}$, О. М. Хомяк ${ }^{2}$ \\ ${ }^{1}$ Харківська медична академія післядипломної освіти МОЗ України \\ ${ }^{2}$ КНП ХОР «Обласна клінічна травматологічна лікарня», Харків. Україна
}

Proximal femur fractures are uncommon injuries in children, accounting for less than $1 \%$ of all fractures per year, but usually result in hospitalization and are at risk of complications. We have designed a device for bone fragments fixation in the case of proximal femur fractures and the method of its application in adults. The device consists of rods that are screwed into the cap of the head, the diaphyseal part and the module, which is located in the subtrochanter area. The rods can be connected to the module at any angle in the frontal plane. The device provides a certain stage of installation of the elements, which allows you to effectively place it with minimal bone destruction. Objective. Share your own experience in the treatment of femoral neck and proximal femur fractures in children. Material. The experience of treatment of 28 children with femoral neck fracture or proximal femur fractures for the period 2005-2020 is presented, 11 of them were treated conservatively with the skeletal traction. Osteosynthesis by the author's device was performed in 17 patients: 15 closed reduction, 2 in case of intertrochanteric fracture, - open reduction. The method of osteosynthesis and postoperative management of patients is described in detail. Results. In children who were treated conservatively, the fracture consolidation was achieved within 5-7 months, in one of them - in the position of varus deformity. In contrast to conservative treatment, children began to walk with crutches after a few days after surgery, with partial weight-bearing on injured limb. The device was removed in 16 patients after 5-8 months, and complete fracture consolidation of the fragments in their anatomical position was noted. There were no pathological tissue reactions to the metal device. Conclusions. The proposed device and method of closed osteosynthesis with its usage in the case of proximal femur and femoral neck fractures in children can be recommended in the practice of pediatric traumatology. Key words. Children, fracture, proximal femur, treatment, device for ostheosynthesis.
Переломи проксимального відділу стегнової кістки - нечаста травма в дітей, щз становить менш ніж 1 \% від усіх переломів на рік, проте, зазвичай, обумовлює госпіталізацію та супроводжується ризиком розвитку ускладнень. Нами створено пристрій для з'єднання відламків у разі переломів проксимального відділу стегнової кістки та методику його застосування в дорослих. Пристрій складається зі стрижнів, які загвинчують у шийку голов$\kappa и$, діафізарну частину і модуль, який розташовують у підвертлюговій зоні. Стрижні можна з'єднати з модулем під будь-яким кутом у фронтальній площині. Пристрій передбачає певну етапність установлення елементів, що дозволяє ефективно його розташувати з мінімальним руйнуванням кістки. Мета. Викласти власний досвід лікування переломів шийки або вертлюгової зони стегнової кістки в дітей. Матеріал. Наведено досвід лікування 28 дітей із переломом шийки або вертлюгової ділянки стегнової кістки за період 2005-2020 рр., 11 із них проліковано консервативно зі застосуванням скелетного витягнення. Остеосинтез авторським пристроєм виконано 17 пацієнтам: 15 проведено закриту репозицію, 2, у разі міжвертлюгового перелому, відкриту. Детально описано методику остеосинтезу та післяопераційного ведення пацієнтів. Результати. У дітей, яких лікували консервативно, зрощення відламків досягнуто в терміни 5-7 міс., у одного з них - у положенні варусної деформації. На відміну від консервативного лікування після остеосинтезу діти через декілька днів починали ходити за допомогою милиць, дозовано приступаючи на ушкоджену кінцівку. Видалення пристрою проведено 16 пацієнтам через 5-8 міс., констатовано повне зрощення відламків в анатомічному їхньому положенні. Патологічних реакиій тканин на металевий пристрій не було. Висновки. Запропонований пристрій і методику закритого остеосинтезу з його використанням у разі переломів вертлюгової зони в дітей можна рекомендувати в практику дитячої травматології.

Ключові слова. Діти, перелом, проксимальний відділ стегнової кістки, лікування, пристрій для остеосинтезу 


\section{Вступ}

Переломи проксимального відділу стегнової кістки є рідкими травмами в дітей і становлять менш ніж $1 \%$ від усіх переломів на рік, проте зазвичай обумовлюють госпіталізацію та супроводжуються ризиком розвитку ускладнень (остеонекроз, coxa valga, передчасне закриття наросткової зони, незрощення) [1]. Такі переломи в дітей виникають здебільшого внаслідок високоенергетичної травми - дорожньо-транспортних пригод, падіння з висоти, занять спортом тощо [2].

Історично основним методом лікування переломів проксимального відділу стегнової кістки в пацієнтів дитячого віку був консервативний $[3,4]$, на який найчастіше орієнтовані дитячі травматологи в Україні. Проте ризик пізнього зміщення відламків обумовив застосування хірургічних підходів до лікувальної тактики таких хворих [5]. Закрита чи відкрита репозиція з внутрішньою стабільною фіксацією за допомогою різних пристроїв стає все більше використовуваною методикою в разі переломів шийки стегнової кістки в дітей [6-8], але достатнього досвіду лікування цих переломів немає.

Нами створено пристрій для з'єднання відламків у разі переломів проксимального відділу стегнової кістки та методику його застосування в дорослих $[9,10]$ (рис. 1). Він складається з титанових стрижнів (рис. 1,1 ) діаметром 6 мм із різьбленням на одному кінці, які загвинчують у шийку та головку стегнової кістки, коротких стрижнів для діафізарної частини (рис. 1,2 ), титанового модуля (рис. 1,3 ), який повторює зовнішній контур підвертлюгової зони стегнової кістки і має отвори для фіксаторів стрижнів (рис. 1, 4).

Стрижні можна зафіксувати до пластини під будь-яким кутом у фронтальній площині. Пристрій передбачає певну етапність установлення

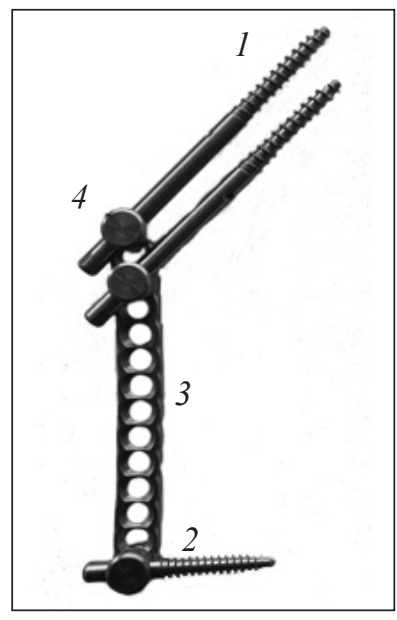

Рис. 1. Вигляд пристрою для напруженого з'єднання відламків у разі переломів проксимального відділу стегнової кістки елементів, що дозволяє ефективно його розташувати 3 мінімальним обсягом руйнування кістки. Пристрій і методика лікування показали високу клінічну ефективність за умов черезвертлюгових переломів стегнової кістки в дорослих $[11,12]$.

Мета роботи: викласти власний досвід лікування переломів шийки або вертлюгової зони стегнової кістки в дітей.

\section{Матеріал і методи}

Матеріали статті розглянуто на засіданні комітету з біоетики при ДУ «ІПХС ім. проф. М. І. Ситенка НАМН України» та отримано позитивне рішення (протокол № 216 від 26.04.2021).

За період 2005-2020 роки в дитячому травматологічному відділенні Харківської травматологічної лікарні перебували на лікуванні 28 дітей із переломом шийки або вертлюгової зони стегнової кістки у віці 5-16 років. Зазвичай, переломи відбулися внаслідок падіння з висоти, спортивного знаряддя або на слизькій поверхні, коли сила діяла безпосередньо на зону вертлюга.

Згідно $з$ класифікацією Delbet [2], переломи розподілилися: шийки стегнової кістки (I-II тип) 22 дитини, черезвертлюговий - 6. В однієї постраждалої, окрім перелому шийки стегнової кістки, діагностовано перелом крила таза з протилежної сторони.

Методика лікування. У всіх постраждалих виявлено первинне зміщення відламків у вигляді кутової деформації. Через це їм відразу використовували систему скелетного витягнення за надвиросткову зону стегнової кістки. У більшості хворих (21) цей метод лікування дав змогу зіставити відламки, а в 7 зміщення лишалося.

В 11 пацієнтів, які перебували у відділенні у 2005-2013 рр., лікування проводили консервативно. Упродовж 1,5-2 міс. застосовано систему скелетного витягнення за надвиросткову зону стегнової кістки, після чого переводили на фіксацію гонітною гіпсовою пов'язкою.

Після 2014 року почали використовувати фіксацію відламків за допомогою вказаного пристрою. У такий спосіб проліковано 17 дітей. Серед них у 14 закрите зіставлення відламків було досягнуто на системі скелетного витягнення впродовж 2 діб, після чого проведено закритий остеосинтез. У 3 хворих після витягнення зміщення відламків не було усунуто, тому провели закриту їхню репозицію під загальним знеболюванням і закритий остеосинтез пристроєм. У більшості (15 осіб) операцію виконано на 3-6-ту добу після травми, у 2 - на 7-9-ту. 
Зупинимося детально на методиці виконання остеосинтезу після закритого зіставлення відламків. Під час операції доцільно використовувати рентгенографію з електронно-оптичним перетворювачем (ЕОП). Якщо хворий перебував на системі витягнення, її знімали і, зберігаючи тракцію кінцівки по осі, доставляли в операційну. Втручання проводили в положенні на спині, кінцівка - в середньо фізіологічному положенні. Усі маніпуляції з проведення спиць і стрижнів виконували за горизонтального положення таза. Під гомілкою розташовували ортопедичну подушку висотою близько $10 \mathrm{~cm}$, кінцівку утримували від зовнішньої ротації. Як показав досвід, положення відламків зберігається під дією помірної тракції за кінцівку. Під час оброблення операційного поля гомілку обертають стерильною тканиною, яку щільно фіксують бинтом для можливості маніпуляцій кінцівкою.

Виконують розріз тканин на рівні підвертлюгової ділянки, позовні, довжиною до 10-12 cм, відповідно довжині накісткового модуля пристрою. Під великим вертлюгом застосовують перфорацію компактної кістки свердлом діаметром 5 мм.

Місце перфорації відрізнялося залежно від боку ушкодження (права чи ліва стегнова кістка). Річ у тому, що конструкція пристрою передбачає з'єднання модуля зі стрижнем фіксатором із різьбовим притисненням. Для того, щоб сила, яка діє на стрижень зверху вниз не розкручувала, а затягувала фіксатор, справа стрижень має бути розташований по передній поверхні модуля, а зліва — по задній. Отже в разі перелому правої стегнової кістки отвір зміщається вперед, а лівої - дозаду (рис. 2).
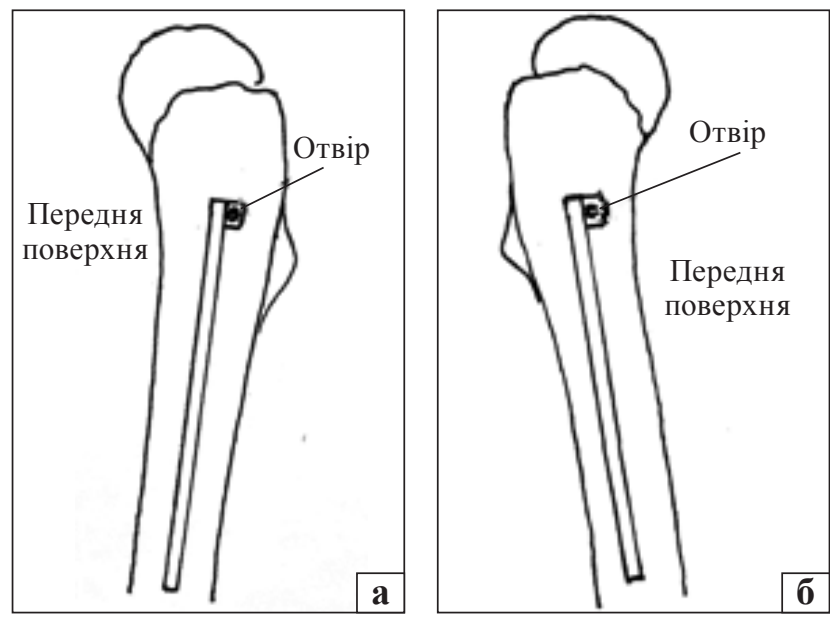

Рис. 2. Місце перфорації стегнової кістки (а - лівої, б правої) у підвертлюговій зоні для введення першого стрижня
Це дає змогу розташувати модуль посередині зовнішньої поверхні стегнової кістки.

Через зроблений отвір заводять спицю, яка має пройти через шийку, у верхньозовнішню частину головки (рис. 3 , а). Використовують ідеально рівні спиці товщиною 1,8 мм і довжиною 160-200 мм. Необхідно їх мати 2-3 штуки однакової довжини. Спицю заводимо на малих обертах і без натискання, щоб не виникла її дугоподібна деформація, яка може змінити обраний напрямок. Під час заведення спиці асистент виконує тракцію кінцівки. Положення спиці контролюємо рентгенологічно, спочатку в передньозадній проєкції, i, якщо вона нас задовольняє, в боковій. Для цього, зберігаючи тракцію, згинаємо кінцівку в коліні та кульшовому суглобі до кута $60^{\circ}-90^{\circ}$ і відводимо стегно на $45^{\circ}$ (положення за Лаунштейном). Центральний промінь спрямовуємо на шийку (рис. 3, б).

Якщо на передньо-задній рентгенограмі положення спиці розцінено як незадовільне, iї проводять повторно.

Під час заведення спиці визначають довжину їі частини, яка розташована в кісткових фрагментах. Для цього потрібно взяти другу спицю такої самої довжини та прикласти до частини, яка виступає 3 кістки. Вимірюють між ним різницю, яка дорівнює довжині частини спиці в кістковій тканині. Ураховуючи цю величину та положення спиці на контрольній рентгенограмі, розраховують необхідну довжину стрижня, обирають його типорозмір і фіксують до ключа-закрутки.

По заведеній спиці розсвердлюють канал трубчастим свердлом діаметром 4,5 мм на глибину, яка відповідає довжині частини стрижня, що має розміщуватися в кісткових відламках. Далі спицю виймають і в канал загвинчують стрижень. У цей момент необхідно зберігати тракцію кінцівки. Глибину заведення контролюють за допомогою рентгенологічного апарата у двох проєкціях. При цьому зовнішній кінець стрижня має виступати на 15-20 мм.

Модуль із фіксатором у крайньому верхньому отворі надівають на кінець загвинченого стрижня та розташовують по зовнішній поверхні стегнової кістки. Попередньо розсікають фасцію та розшаровують зовнішню порцію чотириглавого м'яза. Верхній фіксатор затискають. Через отвір фіксатора, розташований у нижній частині, проводять свердління діафіза свердлом 4,5 мм і загвинчують короткий стрижень (рис. 3 , г). 
На наступному етапі через отвір фіксатора на третьому отворі модуля свердлять компактну кістку свердлом діаметром 5 мм, через нього заводять спицю-орієнтир по нижній частині шийки в головку стегнової кістки та контролюють iii положення рентгенологічно (рис. 3, д). Слід намагатися провести спицю паралельно вже за- гвинченому стрижню. Підбирають стрижень необхідної довжини та після свердління каналу по заведеній спиці трубчастим свердлом загвинчують його в шийку та головку стегнової кістки (рис. 3, е). Виконують рентгенографію у двох проєкціях. Насамкінець максимально затягують гайки усіх трьох фіксаторів.
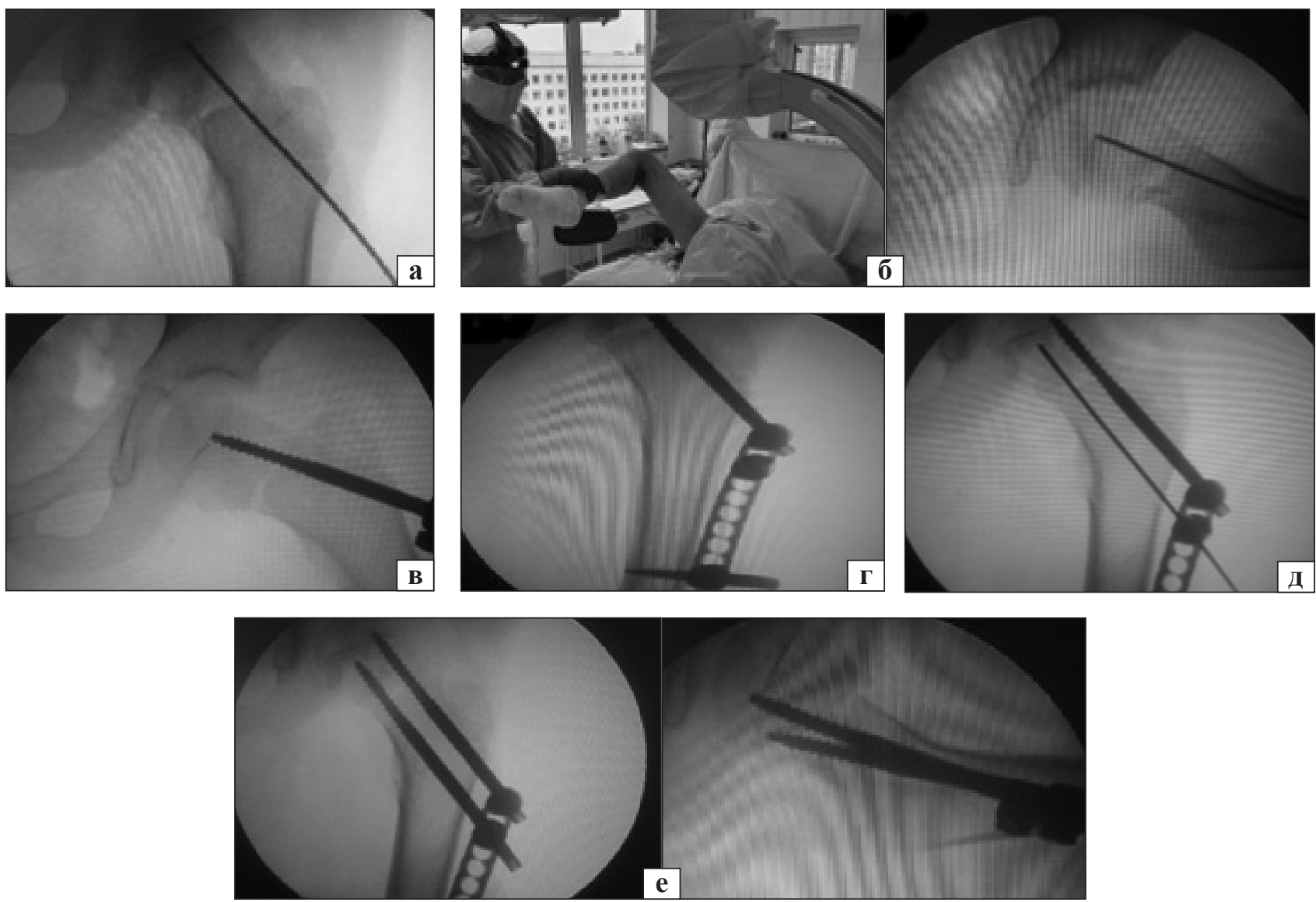

Рис. 3. Етапи остеосинтезу перелому шийки стегнової кістки в дитини П., 9 років: а) заведення спиці-орієнтира та рентгеноконтроль у передньо-задній проєкції; б) рентгеноконтроль у боковій проєкції; в) заведення стрижня після свердління каналу по спиці-орієнтиру; г) фіксація модуля до введеного стрижня та проведення стрижня в діафіз стегнової кістки після попереднього його свердління; д) проведення спиці-орієнтира для другого стрижня та рентгенологічний контроль його положення в передньо-задній проєкції; е) заведення та фіксація до модуля другого стрижня
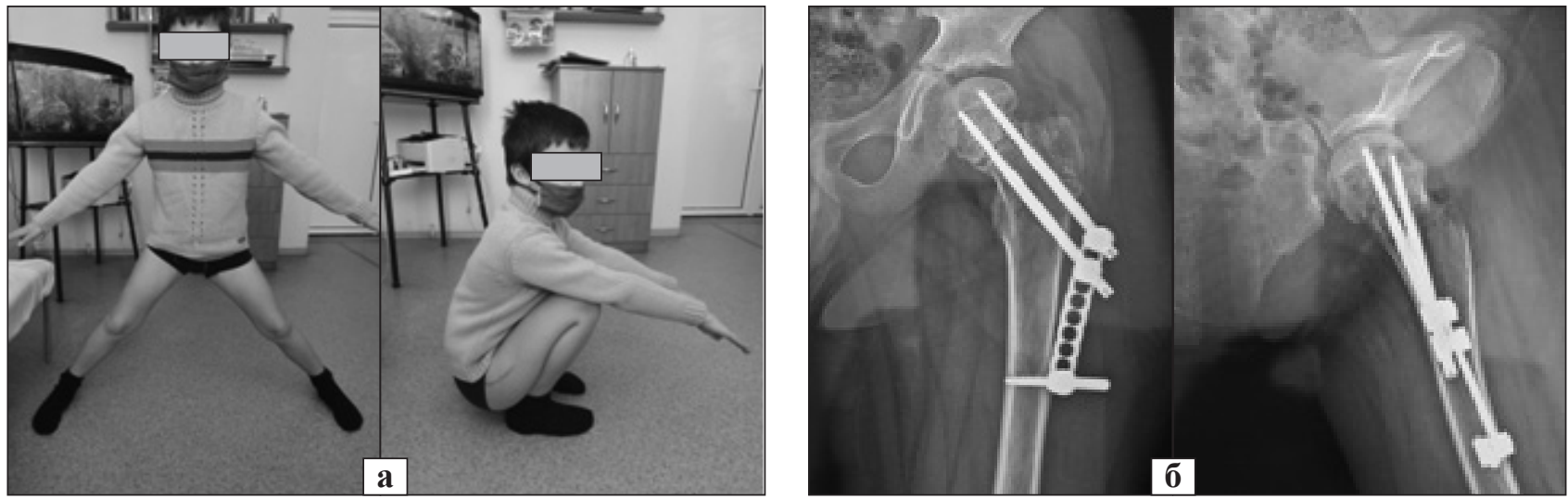

Рис. 4. Демонстрація функції суглобів (а) пацієнта П. та рентгенограми (б) через 5 міс. після операції 
Рану зашивають пошарово наглухо. Модуль опиняється в м'язі під фасцією.

Оскільки більшість дітей були підліткового віку, їм дозволяли через декілька днів після операції ходити за допомогою милиць, дозовано приступаючи на ушкоджену кінцівку. Величина опори відповідала масі кінцівки. Методист або лікар навчав дітей правильній ходьбі 3 милицями 3 дозуванням навантажень і після цього їх виписували на амбулаторне спостереження. Ходьба за допомогою милиць тривала 3 міс., після чого переходили на використання однієї милиці впродовж декількох тижнів, потім дозволяли ходити без додаткової опори. За цей час діти природно відновлювали функцію суглобів ушкодженої кінцівки та притаманну їм рухову активність.

Клінічний приклад № 1

Наводимо вигляд хворого П., 9 років, його рентгенограми через 5 міс. після операції остеосинтезу, етапи якого продемонстровано вище (рис. 4).

\section{Результати та їх обговорення}

Усі хворі протягом лікування, включаючи етап видалення внутрішнього фіксатора або зняття гіпсової пов'язки та подальшого відновлення функції кінцівки, перебували під наглядом у дитячому травматологічному відділенні, особисто завідуючого С. Б. Довганя.

В 11 пацієнтів, яких лікували консервативно, було досягнуто зрощення відламків у терміни від 4 до 7 міс. У 10 була відновлена анатомічна форма проксимального відділу стегнової кістки. В одного зрощення відбулося в положенні варусної деформації. Особливо проблемним виявилося лікування дітей, в яких відламки на системі скелетного витягнення не вправлено, тому ми були вимушені додатково виконувати закрите їхнє зіставлення під загальним знеболюванням (така ситуація склалася у 4 пацієнтів). Після процедури було необхідним зберігати утримуюче положення кінцівки, яким було відведення та внутрішня ротація, що складало технічні труднощі та незручність для дитини. У випадку, коли положення кінцівки порушувалося, виникала необхідність додаткового рентгенологічного обстеження. Термін перебування на системі скелетного витягнення становив 1,5-2 міс. Потім кінцівку фіксували гонітною гіпсовою пов'язкою. У результаті в одного із цих пацієнтів після зняття гіпсової пов'язки було виявлено зрощення в положенні варусної деформації шийки стегнової кістки.

Методика закритого остеосинтезу розробленим пристроєм [10] використана в 17 дітей. Про- аналізуємо деталі значимих етапів. Важливий момент, від якого залежить подальший перебіг загоєння перелому, — це закрите загвинчування стрижнів у шийку та головку стегнової кістки.

Далі - заведення спиці-орієнтира. Відхилення її від заданого хірургом напрямку пов'язано 3 використанням тонкої стандартної спиці Кіршнера, яка прогинається під час свердління компактної кістки. Тому, щоб зберегти обраний напрямок, слід застосовувати максимально товсту, укорочену до мінімальної величини спицю, а заводити її необхідно через попередньо зроблений отвір у компактній кістці. Тоді прогнозовано можна спрямовувати спицю та заводити її на малих обертах. Якщо вона пройшла не за планом, отвір можна використати для проведення іншої спиці в необхідному напрямку.

Свердління каналу має бути проведене на всю глибину, включаючи відповідну ділянку на головці стегнової кістки. Якщо іiї «недосвердлити», виникають труднощі під час проведення стрижня. Губчаста кістка в дітей досить щільна та загвинчування стрижня вимагає значних зусиль, які можуть змістити головку стегнової кістки або утворити діастаз між відламками.

Проводячи два верхні стрижні, слід поетапно контролювати їхне положення за допомогою ЕОП. Перший контроль робили, коли він заглибився приблизно на $2 / 3$ довжини, щоб переконатися, що його напрямок у фронтальній площині відповідає тому, де була спиця. Другий і третій для того, щоб максимально заглибити стрижень у головку та не вийти за їі межі.

У більшості хворих (13 осіб) методику виконано з використанням ЕОП, у 4 - без неї, оскільки спочатку не було в лікарні такого обладнання. Застосовування традиційної рентгенографії забирало багато часу, а спроба прискорити процес призводила до не досить раціонального заведення стрижнів.

\section{Клінічний приклад № 2}

Постраждалий Р., 15 років, отримав перелом шийки стегнової кістки в результаті падіння з гімнастичної перекладини. Відламки зіставлені системою скелетного витягнення на 4-ту добу після травми, виконаний закритий остеосинтез із використанням звичайного пересувного рентгенівського апарата. Спиця-орієнтир пройшла не за планом, яким передбачено іiі введення у верхньозовнішню частину головки стегнової кістки (рис. 5, а). Ураховуючи обмеження з рентгенологічним контролем, ми вирішили скористатися цією спицею для заведення нижнього стрижня (рис. 5, б). 

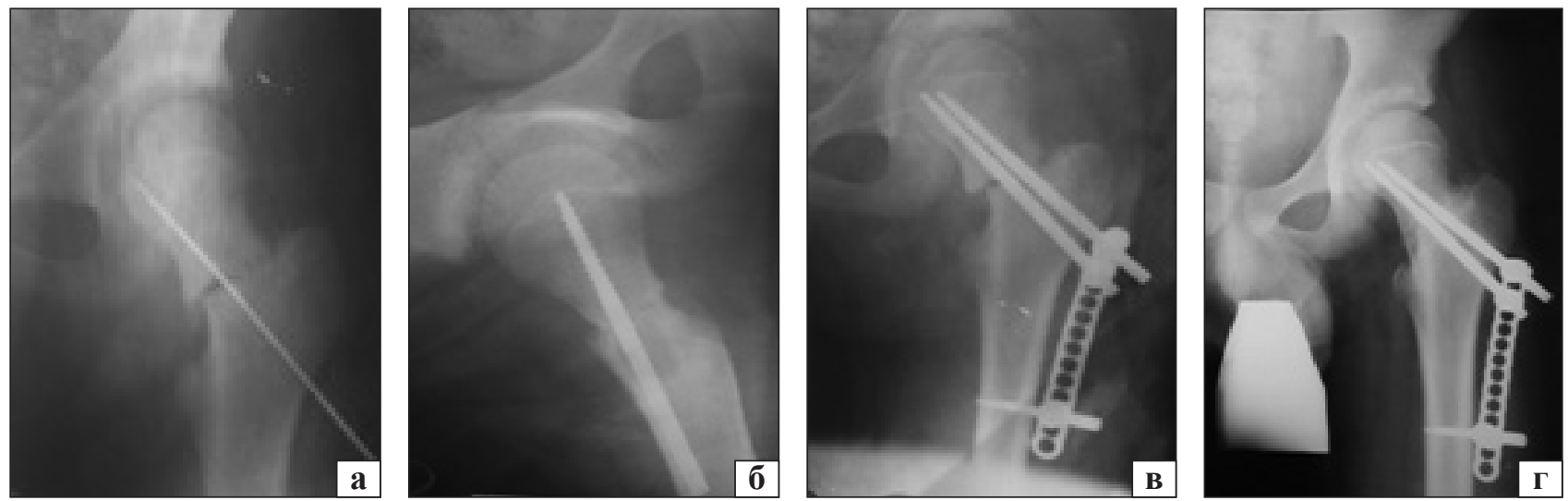

Рис. 5. Рентгенограми хворого Р., 15 років: на операційному столі після заведення спиці-орієнтира (а); профільна після заведення першого стрижня (б) та після з’єднання відламків пристроєм (в); через 3,5 міс. (г)

Першим був заведений стрижень по нижній частині шийки та головки, до нього фіксували модуль. Для цього використали третій отвір зверху. У нижній частині модуль фіксували до діафіза коротким стрижнем. В останню чергу загвинтили стрижень по верхній частині шийки стегнової кістки без попереднього проведення спиці-орієнтира. Провели свердління шийки та головки в напрямку, паралельному заведеному стрижню. На контрольній рентгенограмі з'ясувалося, що верхній стрижень розташувався не найкращим чином (рис. 5 , в). Перепроводити його ми вважали недоцільним через можливість додаткового руйнуванням кістки. Хоча залишилося відчуття допущеної помилки. Слід було спочатку провести спицюорієнтир, а вже по ній - свердління каналу. Але незважаючи на цю похибку процес лікування перебігав без ускладнення і через 3,5 міс. перелом зрісся (рис. 5, г).

Аналіз реакиї̈ тканин і хворого на пристрій, занурений в параосальну зону

Як ми бачимо, особливістю конструкції є розташування поза кісткою. Тому ми цілеспрямовано з'ясовували скарги та функцію кінцівки на предмет негативних явищ із боку фіксатора. Єдине, що нам вдалося виявити, це скарги двох підлітків на незручність, коли вони лежали на оперованому боці на твердій поверхні. У 5-річної дівчинки під час ходьби спостерігали симптом Дюшена-Тренделенбурга, який, імовірно, був пов'язаний із порушенням стабілізаційної функції іліотібіального тракту. Після видалення пристрою цей патологічний симптом зник. Слід звернути увагу, що конструкція зовнішнього модуля та методика встановлення передбачають розташування верхнього краю в заглибленні під великим вертлюгом. У такому разі вся конструк- ція опиняється в товщі м'яза під фасцією і, як ми з'ясували, не спричинює шкідливих ефектів.

Видалення пристрою проведено в 15 пацієнтів за наявності кісткового зрощення відламків через 5-8 міс. після його встановлення. Патологічних явищ у вигляді металозу не спостерігали. Двоє дітей продовжують ходити 3 імплантованими пристроями.

Зрощення відламків в анатомічному положенні фрагментів констатовано в 16 осіб, один перебуває в процесі лікування.

\section{Висновки}

Запропонований пристрій і методику закритого остеосинтезу з його використанням у разі переломів вертлюгової зони у дітей, можна рекомендувати в практику дитячої травматології.

Конфлікт інтересів. Два автори є розробниками та власниками використаного пристрою фіксації відламків стегнової кістки.

\section{Список літератури}

1. Patterson J. T. Management of pediatric femoral neck fracture / J. T. Patterson, J. Tangtiphaiboontana, N. K. Pandya // The Journal of the American Academy of Orthopaedic Surgeons. — 2018. - Vol. 26 (12). — P. 411-419. — DOI: 10.5435/ JAAOS-D-16-00362.

2. Pinto D. A. Fractures of the proximal femur in childhood: a review / D. A. Pinto, A. Aroojis // Indian journal of orthopaedics. - 2020. - Vol. 55 (1). - P. 23-34. — DOI: 10.1007/ s43465-020-00259-4.

3. Корж А. А. Повреждения костей и суставов у детей / А. А. Корж, Н. С. Бондаренко. - Харьков : Прапор, 1994. - $445 \mathrm{c}$.

4. Rockwood and Wilkins' Fractures in Children / Eds. J. H. Beaty, J. R. Kasser. - $7^{\text {th }}$ edition. - Philadelphia : Lippincott, Williams \& Wilkins, 2009. — P. 769-796.

5. Pediatric femoral neck fractures: our 10 years of experience/ K. Bali, P. Sudesh, S. Patel [et al.] // Clinics in Orthopedic Surgery. - 2011. — Vol. 3 (4). — P. 302-308. - DOI: 10.4055/ cios.2011.3.4.302.

6. Hip fractures in children / M. J. Boardman, M. J. Herman, B. Buck, P. D. Pizzutillo // Journal of American Academy of Or- 
thopaedic Surgeons. - 2009. - Vol. 17 (3). - P. 162-173. DOI: 10.5435/00124635-200903000-00005.

7. Medda S. Treatment of young femoral neck fractures / S. Medda, T. Snoap, E. A. Carroll // Journal of Orthopaedic Trauma. 2019. — Vol. 33 (Suppl 1). — P. S1-S6. — DOI: 10.1097 BOT.0000000000001369.

8. Femoral neck fractures in children and the role of early hip decompression in fnal outcome / B. Bukva, D. Abramovic, G. Vrgoc [et al.] // Injury. — 2015. — Vol. 46 (Suppl 6). P. S44-S47. — DOI: 10.1016/j.injury.2015.10.059.

9. Пат. 13777 U (UA). МПК А61B 17/56 (2006.01). Пристрій для лікування переломів шийки та вертлюгової зони стегнової кістки / Попсуйшапка О. К., Побел С. А. : заявник і патентовласник Попсуйшапка О. К., Побел Є. А. — № u200510124; заявл. 27.10.2005 ; опубл. 17.04.2006 ; Бюл. № 4.
10. Свідоцтво про державну реєстрацію $10276 / 211$ «Пристрої стрижневі для з'єднання кісткових відламків при лікуванні переломів кінцівок» ТУ.У 33.1-35700506-001:2011. Згідно 3 наказом Держлікінспекції МО3 України від 15.03.2011 p.

11. Попсуйшапка А. К. Напряжения в конструкции «отломкификсатор» про остеосинтезе переломов шейки бедренной кости различными устройствами / А. К. Попсуйшапка, Е. А. Побел, О. Н. Мананков // Ортопедия травматология и протезирование. - 2006. - № 2. - С. 42-48.

12. Исследование и оценка биомеханической конструкции «отломки-фиксатор», создаваемой про хирургическом лечении переломов шейки бедренной кости / А. К. Попсуйшапка, Е. А. Побел, М. А. Шевцова, Л. С. Белогурова // Ортопедия травматология и протезирование. - 2006. № 4. - C. $55-62$.

\section{OSTEOSYNTHESIS IN CHILDREN WITH FEMORAL NECK AND PROXIMAL FEMUR FRACTURES}

\section{O. K. Popsuishapka ${ }^{1}$, S. B. Dovhan ${ }^{1}$, O. M. Khomyak}

${ }^{1}$ Kharkiv Medical Academy of Postgraduate Education of the Ministry of Health of Ukraine ${ }^{2}$ MNCE of Kharkiv Regional Council «Regional Clinical Traumatological Hospital»

$\triangle$ Olexii Popsuishapka, MD, Prof. in Traumatology and Orthopaedics: alexecorn@gmail.com

$\triangle$ Serhii Dovhan, MD: sbdovgan@gmail.com

$\triangle$ Oleksandr Khomyak, MD: Alexnickkhow@gmail.com 